\title{
ANALISIS PERFORMA ALGORITMA NAIVE BAYES PADA DETEKSI OTOMATIS CITRA MRI
}

\author{
Fajar Akbar¹, Amin Nur Rais², Irwan Agus Sobari³ ${ }^{3}$, Robi Aziz Zuama4, Biktra Rudiarto ${ }^{5}$ \\ Teknik Informatika \\ STMIK Nusa Mandiri Jakarta1235 \\ www.nusamandiri.ac.id, \\ fajar.fkb@nusamandiri.ac.id; aminnurraiskleca@gmail.com; irwan.igb@nusamandiri.ac.id \\ biktra.brd@nusamandiri.ac.id \\ Sistem Informasi \\ Universitas Bina Sarana Informatika ${ }^{4}$ \\ www.bsi.ac.id \\ robi.rbs@bsi.ac.id
}

\begin{abstract}
The brain in humans becomes part of the central nervous system of the human body. The use of imaging with MRI is one that can be used as a first step to detect parts of the human brain. The imaging step is the first step in diagnosing brain tumor. By performing feature extraction, which aims to process the classification of brain tumors, between normal and abnormal brain images using the naive Bayes method. Obtained 41 images which then became 39 datasets. Feature extraction results with 2 classes, normal as many as 20 data and abnormal data 19. The calculation results obtained the value of the normal class of 0.513 and the abnormal class of 0.487 the value of the calculation accuracy of $84.17 \%$.
\end{abstract}

Keywords: Feature Extraction, Brain Tumor, Naive Bayes

Intisari-Otak pada manusia menjadi bagian paling penting dari sistem saraf pusat tubuh manusia. Penggunaan pencitraan dengan MRI salah satunya dapat digunakan sebagai langkah awal untuk mendeteksi bagian otak manusia. Langkah pencitraan medis digunakan sebagai langkah awal pendiagnosisan terhadap penyakit tumor otak. Dengan melakukan ekstraksi fitur, yang bertujuan untuk melakukan proses klasifikasi citra tumor otak, antara citra otak normal dengan abnormal dengan menggunakan metode naive bayes. Didapatkan 41 citra yang kemudian menjadi 39 dataset hasil ekstraksi fitur dengan 2 class, normal sebanyak 20 data dan abnormal 19 data. Hasil penghitungan didapatkan nilai class normal sebesar 0.513 dan class abnormal sebesar 0.487 nilai akurasi penghitungan sebesar $84.17 \%$.

Kata Kunci: Ekstraksi Fitur, Tumor Otak, Naive Bayes

\section{PENDAHULUAN}

Dunia medis terus berkembang dalam segala lini dengan mengikuti perkembangan teknologi. Dimana dalam dunia kedokteran perkembangan teknologi berperan aktif dalam mempermudah dokter untuk melakukan diagnosa suatu penyakit. Seperti dalam pendeteksidan penyakit kanker serviks (Riana, Plissiti, Nikou, Widyantoro, \& Mengko, 2015), dan pendeteksian kanteker pada otak (Nandpuru, Salankar, \& Bora, 2014) teknologi sudah berperan aktif untuk menunjang proses medis. Proses medis dilakukan sebagai tahap untuk melakukan deteksi penyakit yang terdapat pada suatu citra medis dengan melakukan proses pengolahan citra medis. Pengolahan citra dilakukan dengan mengumpulkan citra yang diguanakan sebagai citra masukan untuk mendapatkan informasi yang tertera dari setiap citranya. Tujuan dari proses pengolah citra adalah untuk mengenali citra atau objek yang sedang dipertimbangkan agar lebih mudah divisualkan (Joseph \& Singh, 2014). Untuk mempermudah visualisasi, citra digital dilakukan proses manipulasi citra, yang berguna untuk memperbaiki atau mengurangi kualitas citra, menampilkan bagian tertentu dari citra, membuat citra baru dari beberapa bagian citra yang sudah ada, dan beberapa teknik manipulasi gambar lainnya (Cholis \& Fuad, 2014).

Pencitraan medis adalah teknik dan proses yang digunakan untuk membuat citra anatomi manusia untuk penelitian klinis, diagnosis dan pengobatan (Kaushik, Utkarsha, Singhal, \& Singh, 2014). Penggunaan citra digital didalam dunia medis menjadi sangat penting untuk mempermudah analisa dan diagnosa penyakit yang memiliki resiko tinggi jika dilakukan secara manual dalam memperoleh informasinya, 
dikarenakan citra medis mampu menunjukkan hingga bagian terdalam tubuh manusia (Irawan, Udayanti, \& Nugroho, 2013).

Modalitas pencitraan medis Magnetic resonance imaging (MRI) dan CT-Scan kebanyakan bergantung pada teknologi komputer yang menghasilkan atau menampilkan citra digital dari organ dalam tubuh manusia yang membantu dokter dalam memvisualisasikan bagian tubuh. MRI, CT-scan, dan Radiographic sering digunakan oleh dokter untuk mempermudah mendapatkan analisa dan diagnosa dari penyakit tertentu. Dimana MRI, CT-scan, dan Radiographic melakukan pengambilan alih citra dengan x-ray konvensional, sehingga memungkinkan dokter dapat melihat visualisasi 3 dimensi dari tubuh (Sharma, Diwakar, \& Choudhary, 2012).

Otak pada manusia menjadi bagian paling penting dari sistem saraf pusat tubuh manusia. Penggunaan pencitraan dengan MRI salah satunya dapat digunakan sebagai langkah awal untuk mendeteksi bagian otak manusia. Langkah pencitraan medis digunakan sebagai langkah awal pendiagnosisan terhadap penyakit tumor otak. Tumor Otak adalah pertumbuhan sel - sel abnormal di dalam atau di sekitar otak secara tidak wajar dan tidak terkendali (Yeni Lestari Nasution, Mesran, Suginam, \& Fadlina, 2017). Tumor terjadi karena pembelahan sel yang tidak normal dan tidak terkontrol di otak. Selain itu, Tumor otak terjadi karena pembelahan sel secara tidak normal dan tidak terkendali, baik dari sel itu sendiri ataupun sel kanker yang terjadi pada organ lain yang kemudian menyerang organ otak (Adinegoro, Atmaja, \& Purnamasari, 2015). Hal ini menjadi salah satu jenis pendeteksian penyakit yang memanfaatkan teknologi, dan mendapat banyak perhatian dari peneliti.

Dalam mendeteksi tumor otak, diusulkan teknik fuzzy clustering (Vasuda \& Satheesh, 2010). Algoritma ini menggunakan fuzzy $C$-means, tetapi dalam pengaplikasiannya memiliki kelemahan, dimana algoritma ini memiliki waktu yang lama dalam pengklasifikasian yang diperlukan. Pengklasifikasi membutuhkan data pelatihan yang disegmentasikan secara manual dan kemudian digunakan sebagai referensi untuk melakukan segmentasi secara otomatis terhadap data baru. Penggunaan data latih yang sama untuk mengklasifikasikan sejumlah besar citra, dapat menyebabkan hasil yang bias. Teknik seperti ini yang membutuhkan banyak data latih dan data uji data relatif mempersulit proses (Ananda \& Thomas, 2012).

M.C. Jobin Christ dan R.M.S. Parvathi dalam jurnalnya, mengintegrasikan algoritma klasifikasi dan algoritma segmentasi marker controlled watershed untuk melakukan segmentasi citra medis (Christ \& Parvathi, 2011). Penggunaan Algoritma segmentasi marker controlled watershed untuk melakukan analisa citra medis memiliki keuntungan mampu membangun seluruh pembagian citra medis. Namun, segmentasi dan sensifitas yang berlebihan menjadi kesalahan. Dan menyimpulkan bahwa hasil yang diusulkan mendapatkan hasil segmentasi yang memberikan lebih sedikit partisi daripada hasil segmentasi oleh algoritma segmentasi marker controlled watershed konservatif.

Metode support vector machine pun dapat digunakan dalam melakukan dalam proses pengolahan medis, dalam hal ini melakukan klasifikasi sel darah putih. Dalam pengklasifikasiannya, dengan support vector machine dapat membandingkan hasil dari parameter kernal yang berbeda, yaitu kernel linear dan kernel Radial Basis Function (RBF) (Caraka, Sumbodo, \& Candradewi, 2017). Dari penelitian tersebut, didapatkan bahwa pengklasifikasian sel darah putih dengan metode support vector machine mendapatkan nilai akurasi sebesar $72,26 \%$ dari deteksi sel darah putih dari citra yang dihasilkan dari mikroskop. Dalam penelitian ini, dilakukan proses pendeteksian melalui citra otak normal dan abnormal untuk melakukan proses pengklasifikasian citra tumor otak. Penelitian ini bertujuan menggunakan model naive bayes untuk mendeteksi tingkat akurasi dari citra otak yang tersegmentasi.

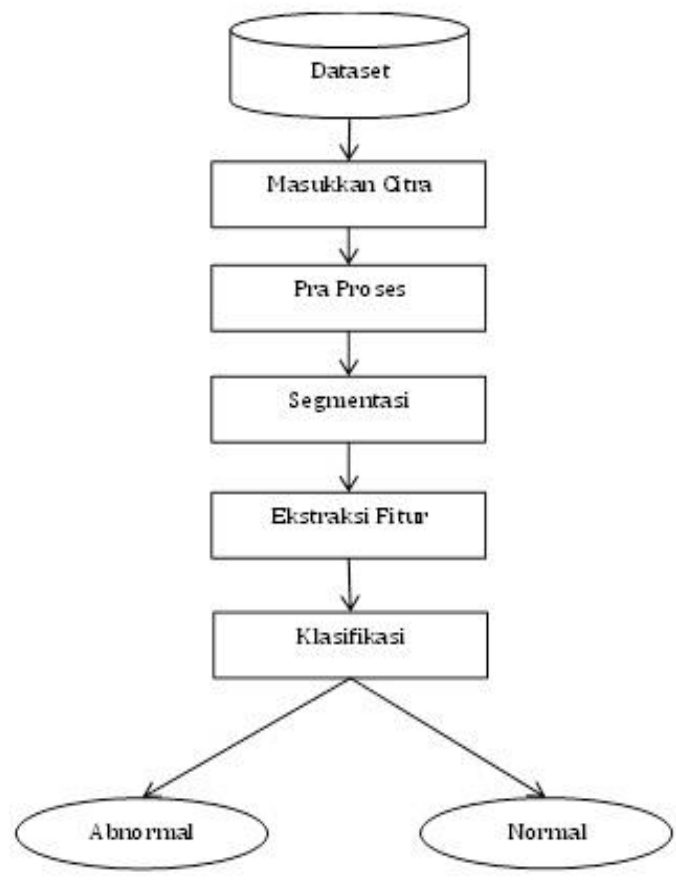

Gambar 1. Model Penelitian 


\section{BAHAN DAN METODE}

Pada modul ini, mengusulkan ekstraksi fitur pada citra otak untuk melakukan klasifikasi citra tumor otak menggunakan teknik pengelompokan dengan metode naive bayes (Gambar 1). Pada tahap awal, pengumpulan citra otak dilakukan dengan menambang dari internet dengan mengambil citra otak yang mengandung tumor (abnormal) dan citra otak yang tidak mengandung tumor (normal).

Setelah citra otak yang akan diolah terkumpul, citra tersebut dilakukan proses seleksi dengan memisahkan citra otak yang normal dengan yang abnormal. Pemisahan tersebut dilakukan untuk mempermudah proses seleksi citra ketika dilakukan proses pemasukan citra ke program untuk diambil fiturnya. Dari citra yang dikumpulkan, diperoleh citra otak normal awal sejumlah 20 citra, dengan citra abnormal 21 citra.

Citra yang berhasil kumpulkan, kemudian dilakukan pra proses untuk menyesuaikan citra dengan proses ekstraksi fitur. Dalam pra proses, dilakukan proses kompresi citra yang bertujuan untuk mengurangi redudansi agar data pada citra dapat disimpan dan ditransmisikan secara efisien (Tearani, 2014). Dari citra yang terkompresi, citra dilanjutkan dengan segmentasi posisi dengan memecah citra menjadi dua, dimana citra pertama citra otak yang terindikasi mengandung tumor dan yang kedua citra tempurung otak (Rais \& Riana, 2018). (Rai \& Chakrabarty, 2019) segmentasi dibandingkan keduanya untuk mendapatkan nilai dari setiap fitur yang dibutuhkan. Dimana fitur luas dari keduanya. Dari fitur - fitur yang didapatkan, nilai tiap fitur dari setiap kelasnya ditambang dan disimpan kembali sehingga terbentuk data set baru hasil dari ekstraksi fitur.

Dataset yang terkumpul dari proses ekstraksi fitur diolah kembali berdasarkan kebutuhan pemodelan dari model yang diusulkan (Gambar 1). Dimana dalam pemodelan, setiap nilai dataset yang terbentuk dikonversi dari bilangan pecahan menjadi bilangan bulat untuk mempermudah proses klasifikasi.

Klasifikasi citra otak digunakan untuk melakukan proses identifikasi obyek kedalam sebuah kelas, kelompok, atau kategori berdasarkan karakteristik yang telah ditentukan sebelumnya (Muhamad et al., 2017). Dalam proses pengklasifikasian, naive bayes dipilih untuk proses klasifikasi citra otak antara citra otak yang normal dan abnormal. Dengan menggunakan naive bayes, sehingga nilai tingkat akurasi dari dataset dapat diketahui untuk menentukan citra otak yang normal dan abnormal.

\section{HASIL DAN PEMBAHASAN}

Pembahasa yang disajikan mengacu ke model yang diusulkan pada gambar 1 . Pada tahap awal, pengumpulan citra otak dilakukan dengan mengambil data citra dari internet dengan mengambil citra otak yang mengandung tumor (abnormal) dan citra otak yang tidak mengandung tumor (normal) (gambar 2).

Citra hasil pengumpulan dari internet kemudian dipisahkan antar citra yang normal dan citra yang abnormal. Proses pemisahan dilakukan untuk mempermudah dalam melakukan proses pemasukan citra kedalam program matlab R2015b yang sudah disiapkan untuk mengekstrak nilai fitur dari setiap citranya. Dari citra yang dikumpulkan, diperoleh citra otak normal awal sejumlah 20 citra, dengan citra abnormal 21 citra.

Dengan menggunakan marlab R2015b, proses penambangan nilai fitur dilakukan. Dalam tahap awal, dilakukan proses pra proses untuk memaksimalkan citra masukan. Dalam pra proses, setiap citra yang diolah dikompres ukurannya sama rata dengan dimensi 250 x 250. Sehingga memungkinkan dalam menentukan luas dasar setiap citra bernilai sama. Dari citra hasil kompresi, citra kemudian dilakukan proses segmentasi seperti pada Gambar 3 dan Gambar 4 untuk mendapatkan posisi tumor pada citra citra dan sisi tepi dari otak. Dengan menggunakan dua citra, dapat dibandingkan antara citra tumor dan citra otak yang telah terpisah.
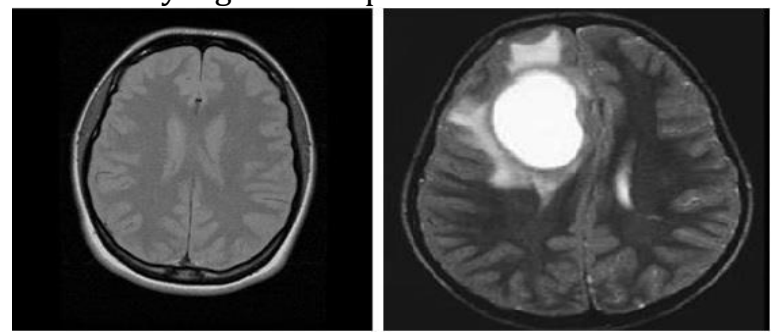

Sumber: (Rai \& Chakrabarty, 2019)

Gambar 2. Citra otak normal dan abnormal

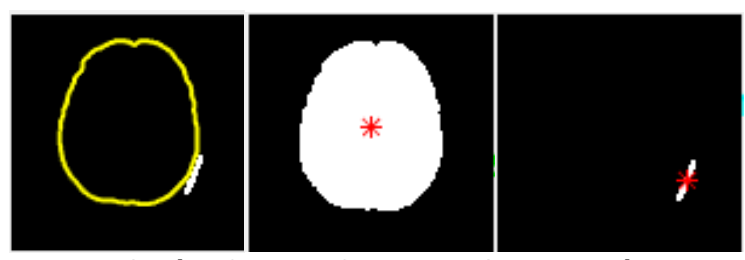

Gambar 3. Proses Segmentasi Citra Normal

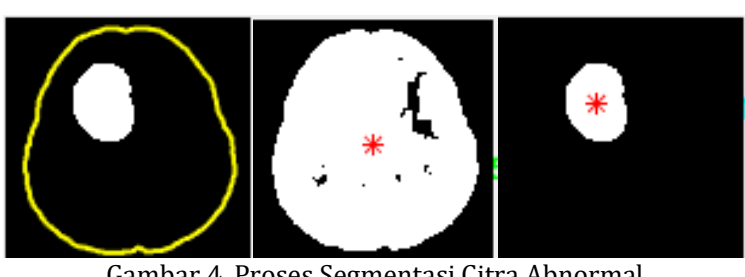

Gambar 4. Proses Segmentasi Citra Abnormal 
Masing - masih citra ditambang nilai setiap fiturnya, dengan penambangan berfokus pada persentase luas dari citra tumor dan citra otaknya.

Penambangan fitur dilakukan untuk mendapatkan data set baru yang berisikan nilai dari setiap citranya. Salah satu nilai yang ditambang adalah luas permukaan yang tersegmentasi. Luas segmentasi citra tomor diambil kemudian dibandingkan dengan citra otak yang tersegmentasi, sehingga dapat dibandingkan keduanya dengan masing - masing luasnya.

Tabel 1. Hasil ekstraksi fitur

\begin{tabular}{rcccccccccccccccc}
\hline No & Ltumor & Ltempurung & Ptumor & Mean & STDev & Entropy & Variance & Class \\
\hline 1 & 145 & 30765 & 0,47132 & 0,00221 & 0,04699 & 0,02270 & 0,00221 & normal \\
\hline 2 & 165 & 30585 & 0,53948 & 0,00252 & 0,05011 & 0,02536 & 0,00251 & normal \\
\hline 3 & 176 & 22695 & 0,77550 & 0,00269 & 0,05175 & 0,02681 & 0,00268 & normal \\
\hline 4 & 203 & 22214 & 0,91384 & 0,00310 & 0,05557 & 0,03028 & 0,00309 & normal \\
\hline 5 & 284 & 19294 & 1,47196 & 0,00433 & 0,06569 & 0,04026 & 0,00431 & normal \\
\hline 6 & 1147 & 21700 & 5,28571 & 0,01750 & 0,13113 & 0,12717 & 0,01720 & abnormal \\
\hline 7 & 2004 & 15991 & 12,53200 & 0,03058 & 0,17217 & 0,19729 & 0,02964 & abnormal \\
\hline 8 & 4199 & 39465 & 10,63980 & 0,06407 & 0,24488 & 0,34340 & 0,05997 & abnormal \\
\hline 9 & 6434 & 31881 & 20,18130 & 0,09818 & 0,29755 & 0,46318 & 0,08854 & abnormal \\
\hline 10 & 2415 & 51300 & 4,70760 & 0,03685 & 0,18840 & 0,22766 & 0,03549 & abnormal \\
\hline
\end{tabular}

Sumber: (Akbar, Rais, Sobari, Zuama, \& Rudiarto, 2019)

Masing - masing dari luas citra hasil segmentasi, dilakukan proses persentase luas dengan membandingkan luas citra otak dibandingkan dengan luas citra tumor, sehingga memunculkan nilai persentase luas tumor dan persentase luas otak. Persentase luas ini menjadi salah satu fitur yang digunakan dalam penambangan data seperti pada Tabel 1 .

Dari hasil penambangan fitur, dapat diolah lebih lanjut sebanyak 39 data set yang terdiri dari citra normal sebanyak 20 data, dan citra abnormal sebanyak 19 data. Dengan menggunakan metode naive bayes dengan persamaan (1)

$P(C \mid X)=\frac{P(X \mid C) P(C)}{P(X)}$

Dengan menggunakan metode naive bayes, memunculkan peluang munculnya setiap kelas citra otak dan menghitung setiap peluang setiap fitur yang ada. Sehingga memunculkan nilai baru untuk menghitung tingkat akurasi datanya. Namun, untuk memaksimalkan penghitungannya, dioptimalkan dengan laplace correction yang berguna untuk menangani nilai probabilitas 0 (nol) dengan persamaan (2)

$P_{i}=\frac{m_{i}+1}{n+k}$

Penghitungan akurasi terhadap fitur dari dataset yang didapatkan dilakukan dengan bantuan tools rapid miner versi 8.1. Dalam rapid miner, diimplementasikan dengan susunan operator seperti pada gambar 5 yang menggambarkan dataset yang dimasukkan dengan format data csv hasil pengolahan microsoft excel.

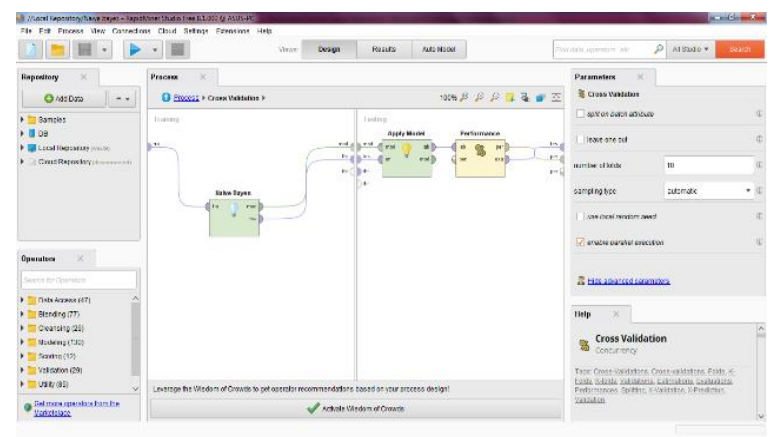

Gambar 5. Skema pengujian naive bayes

Tabel 2. Hasil prediksi

\begin{tabular}{lll}
\hline No & Class & Prediction \\
\hline 1 & abnormal & abnormal \\
2 & normal & normal \\
3 & normal & normal \\
4 & normal & normal \\
5 & abnormal & abnormal \\
6 & abnormal & abnormal \\
7 & normal & normal \\
8 & normal & normal \\
9 & abnormal & normal \\
10 & abnormal & normal \\
\hline
\end{tabular}

\begin{tabular}{lccc}
\multicolumn{4}{c}{ Tabel 3. Hasil akurasi } \\
\hline & $\begin{array}{l}\text { true } \\
\text { abnormal }\end{array}$ & $\begin{array}{l}\text { true } \\
\text { normal }\end{array}$ & $\begin{array}{l}\text { class } \\
\text { precision }\end{array}$ \\
\hline $\begin{array}{l}\text { pred. } \\
\text { abnormal }\end{array}$ & 15 & 2 & $88.24 \%$ \\
\hline pred. normal & 4 & 18 & $81.82 \%$ \\
\hline class recall & $78.95 \%$ & $90.00 \%$ & \\
\hline
\end{tabular}

accuracy: $84.17 \%+/-20.56 \%$ (mikro: $84.62 \%$ ) 
Kemudian diproses dengan cross validation dengan model naive bayes dan laplace correction, dan performance yang berguna untuk memunculkan hasil perhitungan dari model yang diusulkan (gambar 1). Dengan skema pemodelan pada gambar 5, dapat diketahui nilai class dari class normal sebesar 0.513 dan class abnormal sebesar 0.487 dengan contoh hasil prediksi seperti pada tabel 2 dan nilai akurasi penghitungan sebesar $84.17 \%$ (tabel 3).

\section{KESIMPULAN}

Pada ekstraksi fitur tumor otak dengan naive bayes, kasifikasi digunakan untuk melihat tingkat akurasi datanya yang bersumber dari ekstraksi fitur dalam pembobotannya. Dalam pengujian ini, digunakan dataset yang telah terekstrak sebanya 39 data set yang terbagi menjadi 2 class, yaitu class normal dan abnormal. Pada class normal, didapatkan 20 dataset, sedangkan class abnormal 19 dataset yag siap dihitung. Hasil perhitungan akurasi dari fitur yang terekstrak dengan menggunakan model yang diusulkan, mendapatkan nilai class normal sebesar 0.513 dan class abnormal sebesar 0.487 dengan akurasi penghitungan $84.17 \%$. adapun saran dari penelitian ini yaitu metode dalam melakukan ekstraksi fitur agar dilanjutkan dan diperdalam untuk melihat kemungkinan mendapatkan nilai fitur yang lain yang lebih mendalam dengan memodelkan model klasifikasi yang lain.

\section{REFERENSI}

Adinegoro, A., Atmaja, R. D., \& Purnamasari, R. (2015). Deteksi Tumor Otak dengan Ektrasi Ciri \& Feature Selection mengunakan Linear Discriminant Analysis ( LDA) dan Support Vector Machine ( SVM ) Brain Tumor' s Detection With Feature Extraction \& Feature Selection Using Linear Discriminant Analysis ( LDA ). E-Proceeding of Engineering, 2(2), 2532-2539.

Akbar, F., Rais, N. A., Sobari, I. A., Zuama, R. A., \& Rudiarto, B. (2019). Laporan Akhir Penelitian Performa Naive Bayes pada Deteksi Citra MRI. Jakarta.

Ananda, R. S., \& Thomas, T. (2012). Automatic segmentation framework for primary tumors from brain MRIs using morphological filtering techniques. 2012 5th International Conference on Biomedical Engineering and Informatics, BMEI 2012, (March 2015), 238242.

https://doi.org/10.1109/BMEI.2012.651299

\section{5}

Caraka, B., Sumbodo, B. A. A., \& Candradewi, I. (2017). Klasifikasi Sel Darah Putih Menggunakan Metode Support Vector Machine (SVM) Berbasis Pengolahan Citra Digital. IJEIS (Indonesian Journal of Electronics and Instrumentation Systems), $7(1)$,

25. https://doi.org/10.22146/ijeis.15420

Cholis, M. N., \& Fuad, Y. (2014). APLIKASI DETEKSI TEPI SOBEL UNTUK IDENTIFIKASI TEPI CITRA MEDIS. MATHunesa, 3(2), 15-19.

Christ, M. C. J., \& Parvathi, R. M. S. (2011). Segmentation of Medical Image using Clustering and Watershed Algorithms. American Journal of Applied Sciences, 8(12), 1349-1352.

https://doi.org/10.3844/ajassp.2011.1349.1 352

Irawan, C., Udayanti, E. D., \& Nugroho, F. A. (2013). Visualisasi dan Rekonstruksi 3D Citra Medis : Review. SEMANTIK 2013, 2013(November), 61-64.

Joseph, R. P., \& Singh, C. S. (2014). Brain Tumor Mri Image Segmentation and Detection in Image Processing. International Journal of Research in Engineering and Technology, 3(1), 1-5.

Kaushik, D., Utkarsha, S., Singhal, P., \& Singh, V. (2014). Brain Tumor Segmentation using Genetic Algorithm. International Journal of Computer Applications, ICACEA (5), 13-15. https://doi.org/10.15662/IJAREEIE.2016.05 03043

Muhamad, H., Prasojo, C. A., Sugianto, N. A., Surtiningsih, L., Cholissodin, I., Ilmu, F., ... Optimization, P. S. (2017). OPTIMASI NAÏVE BAYES CLASSIFIER DENGAN MENGGUNAKAN PARTICLE, 4(3), 180-184.

Nandpuru, H. B., Salankar, S. S., \& Bora, V. R. (2014). MRI Brain Cancer Classification Using Support Vector Machine. Electrical, Electronics and Computer Science (SCEECS), 2014 IEEE Students' Conference. IEEE., 1-6. https://doi.org/10.1109/SCEECS.2014.6804 439

Rai, S., \& Chakrabarty, N. (2019, May 15). Brain MRI Images for Brain Tumor Detection. Retrieved from kaggle.com: https://www.kaggle.com/navoneel/brain- 
mri-images-for-brain-tumor-detection.

Rais, A. N., \& Riana, D. (2018). Segmentasi Citra Tumor Otak Mengunakan Support Vector Machine Classifier. Seminar Nasional Inovasi Dan Tren (SNIT) 2018, 152-155.

Riana, D., Plissiti, M. E., Nikou, C., Widyantoro, D. H., \& Mengko, T. L. R. (2015). Inflammatory cell extraction and nuclei detection in Pap smear images. International Journal of E-Health and Medical Communications, 6(2), 27-43. https://doi.org/10.4018/IJEHMC.20150401 03

Sharma, P., Diwakar, M., \& Choudhary, S. (2012). Application of Edge Detection for Brain Tumor Detection. International Journal of Computer Applications, Volume 58, 21-25.

Tearani, N. P. (2014). Peningkatan Kompresi Citra Digital Menggunakan Discrete Cosine Transform - 2 Dimension ( DCT - 2D ), 1-5.

Vasuda, P., \& Satheesh, S. (2010). Improved Fuzzy C-Means Algorithm for MR Brain Image Segmentation. International Journal on
Computer Science and Engineering, 2(5), 1713-1715.

Yeni Lestari Nasution, Mesran, M., Suginam, S., \& Fadlina, F. (2017). Sistem Pakar Untuk Mendiagnosis Penyakit Tumor Otak Menggunakan Metode Certainty Factor (Cf). Jurnal INFOTEK, 2(1), 0-4. Retrieved from http://ejurnal.amikstiekomsu.ac.id/index.ph p/infotek/article/view/98 